\title{
Status and conservation of the sun-tailed guenon Cercopithecus solatus, Gabon's endemic monkey
}

\author{
David Brugière and Jean-Pierre Gautier
}

\begin{abstract}
The conservation status of the sun-tailed guenon Cercopithecus solatus, which is endemic to central Gabon, is assessed using the most recent information available. The known range of the species covers 11,000$12,000 \mathrm{sq} \mathrm{km}$, an area with a sparse human population but where the logging activity is widespread. There is no evidence of a recent reduction of the population size of this monkey, mainly because trees are extracted at a low rate (1-2 trees/ha), which does not cause a significant change in the forest composition and structure, and because hunting pressure is currently low. Moreover, the species is suspected to be able to thrive in degraded secondary forests. Consequently, the sun-tailed guenon
\end{abstract}

does not appear to be under immediate risk of extinction. The conservation actions undertaken to date are described and the threats that may affect the monkey in the near future are discussed. Commercial bush-meat hunting is considered to be the most serious threat for the species. Recommendations for the conservation of wild populations and habitat are proposed, and emphasis is placed on co-operation with the forestry companies that are the main economic actors in the species's range.

Keywords Bush-meat trade, Cercopithecus solatus, conservation status, Gabon, logging impact, primate conservation.

\section{Background}

The sun-tailed monkey Cercopithecus solatus Harrison, 1988 , is the most recent diurnal primate species to be discovered in Africa. Indeed, the story of its discovery is uncommon: while exploring the forest of Gabon in the 1940s, Malbrant \& Maclatchy (1949) noted that the Preuss subspecies of the mountain monkey, Cercopithecus lhoesti preussi, then known to occur in south-west Cameroon and Fernando Po (Bioko) Island, was possibly present in Gabon. However, they were unable to confirm this. More than 40 years later, in 1984, a monkey with a colour pattern similar to Preuss's monkey was discovered in central Gabon by M. Harrison. The discovery of this new form of lhoesti led to a taxonomic revision of the whole lhoesti group. Studies of the phenotype, karyotype and vocal repertoire of the Gabonese form (Harrison, 1988a; Dutrillaux et al., 1988; Gautier, 1988a; respectively) led to its being accorded full species status. The new species is now incorporated into the lhoest $i$ super-species together with $C$. (lhoest $i$ ) lhoesti (distributed in eastern Democratic Republic of Congo, western Uganda and Rwanda; Lernould, 1988)

David Brugière (corresponding author) and

Jean-Pierre Gautier Station de Recherche de la Makandé, Gabon Present address: CNRS-UMR 6552, Université de Rennes-I, Station Biologique, 35380 Paimpont, France. Tel: +33 2 99618155;

fax: + 332 99618188; e-mail: David.Brugiere@univ-rennes1.fr and C. (lhoesti) preussi, and the full species status of the three thoesti is now widely accepted (Lernould, 1988; Wilson \& Reeder, 1993; Oates, 1996; Kingdon, 1997) (Plates 1 and 2).

The sun-tailed guenon is of great conservation concern because its range is among the smallest of any African primate, being restricted to the forests of central Gabon. Because of its small range it was classified as Highly Vulnerable in the first Action Plan for the Conservation of African Primates (Oates, 1986) and Vulnerable in the Threatened Primates of Africa: IUCN Red Data Book (Lee et al., 1988). Using the new IUCN Red List categories, the monkey was classified as Vulnerable (IUCN, 1996), but little information was available at the time of the status assessment.

From 1993 to 1996, a socio-ecological study of the species and several field surveys in its range were carried out. The first estimate of its population density and new data on its range became available recently (Brugière, 1998a; Brugière et al., 1998; respectively). In this paper we review the information currently available on the sun-tailed guenon and assess its status. The conservation actions achieved are presented and recommendations for future actions are proposed.

\section{Status}

\section{Distribution}

The sun-tailed guenon was first believed to be endemic 


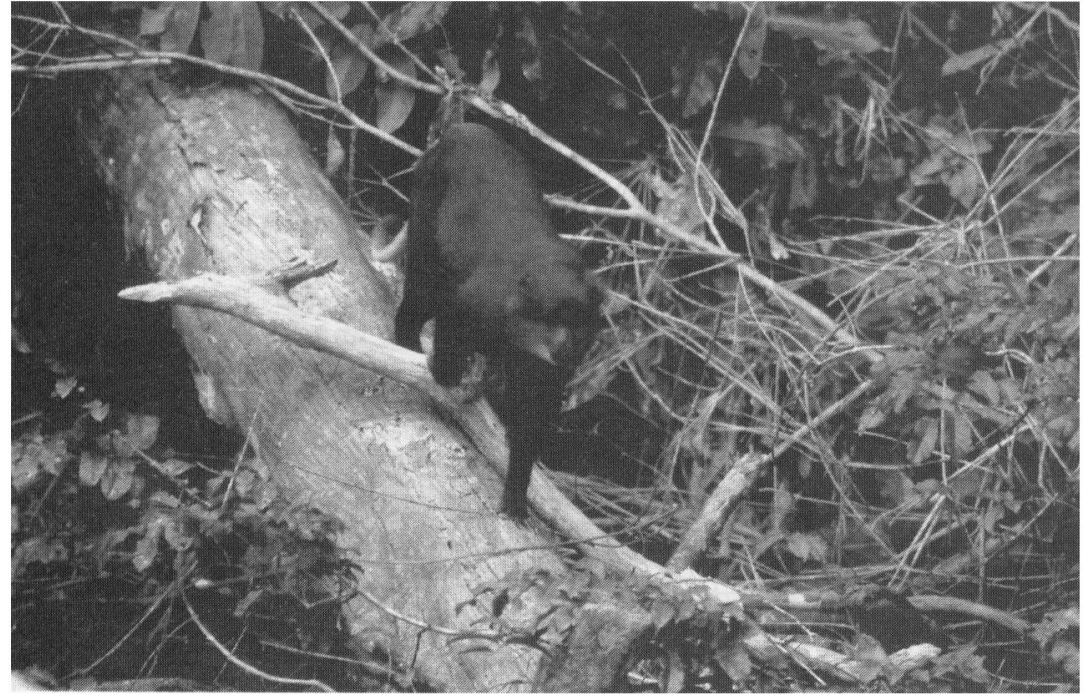

Plate 1 One of the few photographs of a wild Cercopithecus solatus, an adult male at the Makandé Field Station (Jean-Louis Doucet). to the Forêt des Abeilles (forest of bees; Harrison, 1988a), an almost uninhabited forested area of about $10,000 \mathrm{sq} \mathrm{km}$ between the Offoué and Ogooué rivers in central Gabon (Fig. 1). Extensive surveys confirmed that the species occupied an unfragmented range of $10,300 \mathrm{sq} \mathrm{km}$ (Gautier et al., 1992). However, Gautier et al. (1992) suggested that the sun-tailed guenon could occur to the west of the Foret des Abeilles, on the left bank of the Offoue river. Observations by White \& Mackanga (1995) and C. Wilks (pers. comm.) in the south of the Lopé Reserve confirmed this, and subsequent surveys carried out in the new area resulted in a range increase to $11,000-12,000 \mathrm{sq} \mathrm{km}$ (Brugière et al., 1998). The western limit of the range remains unclear because it lies in a remote mountainous area where surveys are difficult and where the monkey probably occurs at very low density.

\section{Density estimates}

The density of $C$. solatus was estimated using the line transect technique in two sample areas. At the Makandé Field Research Station $\left(0^{\circ} 40^{\prime} 39^{\prime \prime} \mathrm{S}, 11^{\circ} 54^{\prime} 35^{\prime \prime} \mathrm{E}\right.$, Fig. 1), based on censuses carried out in a selectively logged forest, the density was estimated at 25.02 individuals per sq $\mathrm{km}$ (transect length, $2.35 \mathrm{~km} ; 40$ censuses over a period of 1 year; total distance censused, $94 \mathrm{~km}$; Brugière, 1998a). In the second area, primary forest in the southern mountainous part of the Lopé Reserve, near the proposed western limit of the distribution, it was not possible to estimate the density reliably because the guenon was encountered so infrequently (Brugière et al., 1998). However, comparing the encounter rate with that found at Makandé, the density in the second area may be about 10 times lower. The differ- ence was correlated with altitude; C. solatus density decreases dramatically beyond $500-550 \mathrm{~m}$ above sea level. The reasons for this are still unclear because there

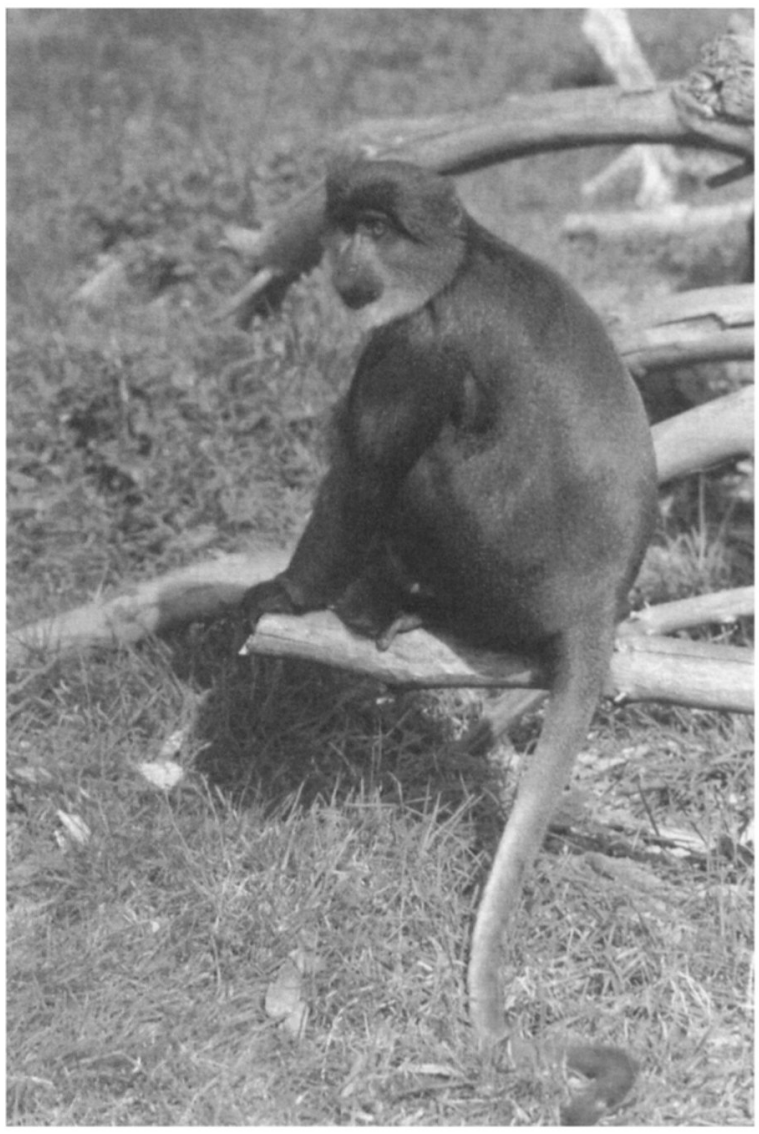

Plate 2 Cercopithecus solatus adult male, 11 years old (Unizersity of Rennes). 
is no significant difference in the forest composition and structure above $500-550 \mathrm{~m}$. However, botanical studies included only tree species over $10 \mathrm{~cm}$ diameter at breast height (d.b.h.) and therefore may have not detected a possible change in the composition of the undergrowth, where $C$. solatus mainly feeds. Consequently, a lower availability of food resources may explain this pattern of distribution. Historical factors (such as a possible recent increase in the range of the species), however, may also be partly responsible see Brugière, 1998a; Brugière et al., 1998). The observed decrease in densities with increasing altitude between the Makandé and south Lopé study areas confirms previous observations made in the southern mountainous part of the range of the species (see Gautier et al., 1992). As a result we propose that the range of $C$. solatus can be divided in two zones: a zone with high population density covering the lower part of the range, approximately 80 per cent of the total, and a low-density zone covering the mountainous part of the range (Fig. 1). In the west, the Offoue river is the limit between the mountainous area in the Lopé Reserve and the Forêt des Abeilles, which lies at lower altitude.

\section{Population size reduction}

The main human activities that are likely to have a detrimental impact on the population size of $C$. solatus are hunting and habitat alteration through logging. The human population within the species's range is very low and only part of the southern limit of the distribution (along and south of the road RN6; Fig. 1) occurs in a moderately inhabited area. Apart from this, there are probably fewer than 5000 humans scattered in c. 25 small villages (mainly grouped along the RN3) and in four logging camps. Hunting is common around villages and logging camps, but hunters report that the sun-tailed guenon is difficult to hunt because of its cryptic behaviour. However, non-selective ground snares set for duikers are a threat to this terrestrial guenon; dead monkeys generally bear signs of snares on wrists and ankles. Forestry workers usually set ground snares while working in the forest but they move frequently, following the felling schedule, and consequently the impact of hunting on the $C$. solatus population is probably low. A survey of the game species killed by forestry workers carried out at the largest logging camp in the Forêt des Abeilles (c. 1500 inhabitants) showed that $C$. solatus are seldom caught: less than 6 per cent of the primates killed belong to this species ( $n=169 ; 133$ days sampled over a period of 1 year; 10 species of primate recorded; Boussougou, 1995).
This survey began just after the species was classified as protected and most of the hunters were not aware of its new legal status. Consequently, the results are not likely to be significantly biased by hunters trying to conceal the fact that they were killing a protected species. Combined with the low human population in the Forêt des Abeilles, these results suggest that hunting pressure is currently too low to have significantly reduced the population size of the species.

The Forêt des Abeilles has been entirely allocated to logging companies and within a few years virtually no place will remain unlogged. By mid-1998, only the southern part of the forest (to $c .1^{\circ} 00^{\prime} S$ ) was still unlogged. Until now, logging has been carried out at a low rate of extraction (1-2 trees/ha; Lasserre \& Gautier-Hion, 1995) and this has not resulted in significant change in the forest structure and composition. For example, at the Makandé Field Station, there is no significant difference in the species composition nor in the number of trees (d.b.h. $>10 \mathrm{~cm}$ ) between logged and unlogged areas (Doucet, 1996). Observations on the socio-ecology of the species has shown that $C$. solatus troops frequently use logged areas because dense secondary vegetation is suitable for this cryptic species and because preferred foods (such as herbaceous plants and insects) are more abundant. Similarly, when the hunting pressure is moderate, monkeys occur around villages in heavily degraded vegetation, occasionally raiding rops (Gautier et al., 1992). This suggests that habitat modification through light logging or small-scale clearing is not likely to have a negative impact on the population density. Although unproven, it is suspected that $C$. solatus may reach a higher density in secondary forest than in primary forest. Finally, there is currently no evidence of a recent reduction of the population size of the sun-tailed guenon as a result of human activities.

\section{Conservation}

In 1988, while assessing the conservation measures needed for the protection of the sun-tailed guenon, four measures were proposed (Gautier, 1988b): (i) place the species on the protected species list and carry out an awareness campaign; (ii) enlarge the Lopé Reserve in order to include part of the Forêt des Abeilles in a protected area; (iii) start a captivebreeding programme; and (iv) carry out socio-ecological studies in the wild with special emphasis on population density. Ten years later, the actions listed below have been achieved. 


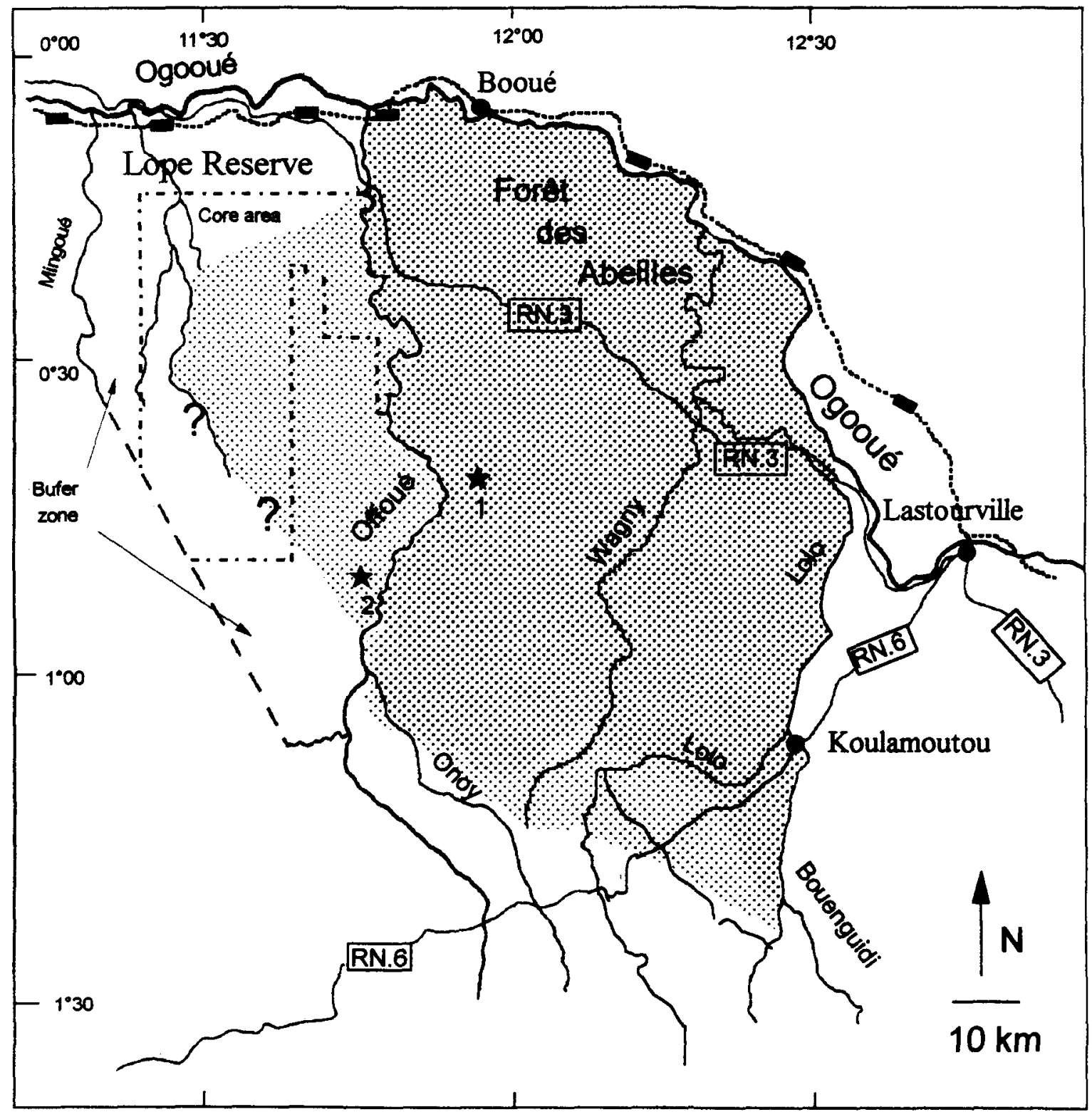

$\because$

High density zone (lowland under $500-550 \mathrm{~m}$ asl)

Low density zone (mountainous area)

RN.3- Main Road (Route Nationale)

............ Trans-Gabonais railway and station

? Distribution limit unclear

$\star \quad$ Places where census surveys were carried out

$$
\begin{aligned}
& 1=\text { Makandé Field Station } \\
& 2=\text { Lot } 32
\end{aligned}
$$

Fig. 1 Range of Cercopithecus solatus, showing the variation in densities. 


\section{Legal status and awareness}

The species was added to Gabon's list of fully protected species in July 1994. In order to give it international protection and because of its IUCN Vulnerable status, it was proposed that the sun-tailed guenon be placed on Appendix 1 of the Convention on International Trade in Endangered Species of Wild Fauna and Flora (CITES; Gautier, 1988c; Butynski, 1996). The Gabonese government, however, did not present the proposal at the Ninth Conference of the Parties at Fort Lauderdale, USA, 7-18 November 1994. Thus, as for all primate species not listed in Appendix I, the suntailed guenon is currently listed in Appendix II.

The survey on hunting pressure carried out by Boussougou (1995) revealed that most of the hunters interviewed were ignorant of the legal status of game species, including that of the sun-tailed guenon. Consequently, an awareness campaign about the ecology and the status of the forest wildlife species, using the sun-tailed guenon as a flagship species, was carried out in 1995 and 1996. Special emphasis was placed on the logging camps because they hold the greatest human concentration in the Forêt des Abeilles. The impact of this campaign is difficult to measure. However, during the campaign, some forestry workers told us about their encounters with troops of suntailed guenon, and some hunters spontaneously told us that they had released monkeys caught in ground snares. Although anecdotal, these accounts show that the sun-tailed guenon is no longer considered to be the same as other monkey species, and that some people are aware that it is unique to the region. Lectures were also given at the Ecole Nationale des Eaux et Forêts in Libreville, the school where forestry officers in charge of wildlife law enforcement are trained. In addition, several articles were published in national newspapers.

\section{Captive breeding}

Using young monkeys taken from hunters, captive colonies were founded in 1986 in Gabon (Centre International de Recherche Médicale de FrancevilleCIRMF) and in 1987 in France (University of Rennes). The CIRMF colony started with four wild individuals ( 2 males, 2 females), and thrived; it currently numbers 11 monkeys (P. Peignot, pers. comm., September 1998). In 1995 , the colony was placed in a 0.5 -ha rain-forest enclosure where its behaviour (e.g. use of space, activity budget) is monitored (Peignot et al., 1996). The French colony, founded with three wild individuals ( 2 males, 1 female), received two additional wild monkeys (1 male, 1 female) in 1989. This colony, which cur- rently comprises two individuals (2 males), failed to thrive because the first female died just after reaching sexual maturity and the second female refused to feed her infants. Because the species is not under immediate risk of extinction, there are no other plans to found another captive colony.

At the Makandé Field Station, an attempt to reintroduce into the wild a young sun-tailed guenon male (age 5 months) taken from hunters was carried out from 1994 to 1996 (Fleury \& Gautier, 1998). The experiment showed some positive results but was prematurely ended because the station closed in December 1996.

\section{Protected area}

The creation of a protected area was recommended by Gautier (1988b) and Harrison (1988b); Wilks (1990) proposed a $2500-\mathrm{sq} \mathrm{km}$ area in the centre of the Forêt des Abeilles. However, this proposition did not receive full support from the government because the proposed boundaries encompass the logging concessions of the second largest forestry company in Gabon (Leroy-Gabon). This company is active in the area and still has two concessions to log (about 170,000 ha). About 10 per cent of $C$. solatus's range is included in the Lopé Reserve, but it is in the lowdensity zone and only a small part is included in the fully protected core area of the reserve (logging concessions have been granted in the whole buffer zone except north of the core area; hunting is forbidden in these concessions). As a result, a significant part of the species's range is unprotected.

\section{Scientific research}

Scientific research on wild sun-tailed guenons was carried out at the Makandé Field Research Station from 1993 to 1996. Three radio-collared troops were monitored and data on the socio-ecology of the species (such as home range size and use, group size and composition, and diet) were collected. In terms of conservation, the most important results are that logging at a low rate of extraction (1-2 trees/ha) does not result in a decrease in population density and that the species uses logged areas. Currently, all field work has been completed and is being written up. Because the cryptic behaviour of the species makes its study in the wild quite difficult (Gautier \& Elkin, 1995), observations of the captive colonies may provide important data on the biology and ethology of the species. Studies are ongoing on the two captive colonies (see Peignot $e t$ al., 1996 for the CIRMF colony). 


\section{Prospects and recommendations}

Until the 1990s, the RN3 was the only road to cross the Forêt des Abeilles. In recent years, increasing forest exploitation has led to the creation of a dense network of logging roads throughout the forest. Such a network makes previously remote areas accessible and may attract commercial bush-meat hunters. As hunting areas near towns have become depleted, hunters have begun to explore remote areas. In March 1996, two dead sun-tailed guenons were seen in a bush-meat market in Libreville, $400 \mathrm{~km}$ from the monkey's range (Pearce, 1996). This may signal the onset of commercial hunting in the Forêt des Abeilles because the species was not seen in previous bush-meat surveys in this town (Steel, 1994). The increasing human population-and consequently the increasing demand for bush meat-in nearby towns such as Koulamoutou, Booué and Lastourville (which together numbered c. 22,000 inhabitants in 1993) will certainly encourage the expansion of the bush-meat trade. In this context, the strict enforcement of the ban on hunting of protected species is the top priority for the conservation of the sun-tailed guenon. In neighbouring countries such as Cameroon and Congo, logging trucks play a major role in the bush-meat trade in remote areas where logging activity occurs (Ammann \& Pearce, 1995; Usongo \& Curran, 1996), so control should be targeted at forestry vehicles. Because there are few roads leaving this forest, control of the bush-meat trade in the area would not be an impossible task. In the northern part of the forest, it would be easy to set a checkpoint at the single bridge that crosses the Offoue river and in the south, checks should be made at the entrance to the towns of Lastourville and Koulamoutou. Control should also focus on the railway stations that border the Forêt des Abeilles because the Trans-Gabonais Railway is known to play an important role in the bush-meat trade: meat is regularly collected at the small stations for transport to large towns (Steel, 1994). Bush-meat control would probably be more effective if done in close co-operation with forestry companies. In 1995, the Leroy-Gabon forestry company operating in the Forêt des Abeilles banned all commercial hunting in its concessions, including the transportation of hunters and bush meat on logging trucks. Other companies should be encouraged to adopt similar policies.

Control of forestry trucks alone will not be enough to regulate the trade because commercial hunters often use their own cars and operate in areas where logging no longer occurs. Poaching activity usually intensifies shortly after forestry companies leave their concessions, mainly because roads are still passable. Consequently, forestry companies should be obliged to make their roads impassable once exploitation is completed in order to prevent the entry of other vehicles. It was proposed that companies destroy key road bridges (Pearce, 1996) but this proposal did not receive full support because bridges are expensive to build and may be reused when old concessions are reopened to prospecting and logging. An alternative proposal could be to place large logs across roads. This system would be rapid to set up, cheap, effective and likely to receive the support of forestry companies because logs are easily removed with appropriate forestry equipment.

The creation of a protected area would also be a good step for the conservation of the wildlife of the Forêt des Abeilles. In addition to the presence of the endemic sun-tailed guenon, this forest harbours several threatened species, including gorilla Gorilla gorilla, chimpanzee Pan troglodytes, black colobus Colobus satanas and elephant Loxodonta africana. This protected area would also benefit plant conservation because the Forêt des Abeilles has the highest diversity of Cesalpiniaceae tree species in Gabon (Wilks, 1990). However, mainly because most of the forest in Gabon has been allocated as forest exploitation concessions, the Gabonese government has never strongly supported the creation of protected areas (for a review of the history and the problems affecting the protected area network, see McShane, 1990; Tutin, 1992; Brugière, 1998b).

The creation of a protected area in the Forêt des Abeilles will not be easy: the forest has been divided into 14 logging concessions and land tenure was transferred to forestry companies with leases of up to 17 years' duration. Hence, a more pragmatic approach might be to propose a conservation area where logging has recently stopped-the area north of RN3 for example. One could argue that primary forests are more important for the conservation of biodiversity but, in the local context, protection of a large tract of unlogged forest is not feasible. Moreover, because logging practices in central Gabon have a low impact on large- and medium-sized mammals (including primates; White, 1992; Brugière, 1998a,c), wildlife protection and management in logged areas are still relevant. This protected area would be an adequate place for continuing research on the sun-tailed guenon. It would be necessary to sample more areas in order to calculate a reasonably reliable population size. In addition, more studies are necessary to assess the impact of logging on population density, especially when there are several waves of cutting. These studies will need to sample areas in active logging concessions and will therefore require co-operation with forestry companies. This underlines a general problem in the Forêt des Abeilles: given the strength of the forestry 
Table 1 Conservation measures proposed for the protection of Cercopithecus solatus

\begin{tabular}{|c|c|}
\hline Themes & Actions needed \\
\hline $\begin{array}{l}\text { Protection of wild } \\
\text { population }\end{array}$ & $\begin{array}{l}\text { Control of commercial hunting with } \\
\text { special emphasis on logging camps, } \\
\text { railway stations and large towns } \\
\text { Make logging roads impassable once } \\
\text { exploitation ceases }\end{array}$ \\
\hline $\begin{array}{l}\text { Protection of } \\
\text { habitat }\end{array}$ & $\begin{array}{l}\text { Set up a protected area } \\
\text { Minimize human settlement in the Forêt } \\
\text { des Abeilles }\end{array}$ \\
\hline $\begin{array}{l}\text { Scientific } \\
\text { research }\end{array}$ & $\begin{array}{l}\text { Sample new areas with density estimates } \\
\text { in order to assess the population size of } \\
\text { the species } \\
\text { Investigate the impact of severe logging } \\
\text { on population density } \\
\text { Continue investigation of the western } \\
\text { distribution of the species }\end{array}$ \\
\hline $\begin{array}{l}\text { Legal status and } \\
\text { legislation }\end{array}$ & $\begin{array}{l}\text { Place the species on CITES Appendix I } \\
\text { Continue the awareness campaign, } \\
\text { especially in towns with bush-meat } \\
\text { markets } \\
\text { Oblige logging companies to control the } \\
\text { bush-meat trade on their concessions and } \\
\text { to monitor the impact of logging }\end{array}$ \\
\hline
\end{tabular}

lobby, few long-term research and conservation activities are likely to be conducted without collaboration with forestry companies. Some companies are receptive to wildlife research and conservation, and they are also under pressure to adopt sustainable management policies as a result of the growing debate on the future of tropical forests (and, more pragmatically, by the fear of tropical wood boycotts by western consumers). The opportunity should be seized to make logging companies aware of their responsibilities regarding the future of tropical wildlife and to prompt them to monitor systematically the impact of their activities on wildlife species. A new forestry law is currently in preparation in Gabon and efforts are under way to introduce sustainable management policies with wildlife conservation measures. The proposed measures for the conservation of the sun-tailed guenon are summarized in Table 1.

\section{Conclusion}

As long as the Forêt des Abeilles remains relatively uninhabited, selectively logged and free from commercial hunting, the sun-tailed guenon will remain safe. The demographic and economic factors necessary for a significant change in the human population of this area are unlikely to occur in the next few years. However, because of the presence of three large towns nearby, commercial hunting will probably have an impact on the Forêt des Abeilles in the near future. This is certainly the most serious threat for the sun-tailed guenon, and wildlife law enforcement is crucial. This task would be more effective if carried out in close co-operation with forestry companies, the main economic actors in the region. Such co-operative work represents a true challenge for both partners. The future of tropical forests and their wildlife species probably rests on the ability to conclude and manage such agreements.

\section{Acknowledgements}

Studies on the sun-tailed guenon were funded mainly by the European Union (DG VIII-Bruxelles and the Gabonese Delegation), and the awareness campaign was funded by WWF-France and the Primate Society of Great Britain. The Leroy-Gabon forestry company provided logistical support. We are grateful to Dr A. T. C. Feistner for comments on versions of the manuscript and for the improvement of the English. Thanks to Dr T. O. McShane and an anonymous referee for their critical comments on the submitted manuscript.

\section{References}

Ammann, K. \& Pearce, J. (1995) Slaughter of the Apes: How Tropical Timber Industry is Devouring Africa's Great Apes. World Society for Protection of Animals, London, UK.

Boussougou, R. (1995) Estimation de la pression de chasse dans un chantier d'exploitation forestière au Gabon-Cas de la Société Leroy-Gabon dans la Forêt des Abeilles. Station de Recherche de la Makandé, Gabon.

Brugière, D. (1998a) Facteurs de variations des densités et des biomasses de primate en milieu tropical forestier: l'exemple des communautés de Cercopithecidae d'Afrique Centrale. Thèse de Diplôme Doctoral, Université de Rennes I, France.

Brugière, D. (1998b) Aires protégées et diversité biologique au Gabon. Bois et Forêts des Tropiques, 255, 45-58.

Brugière, D. (1998c) Population size of the black colobus monkey Colobus satanas and the impact of logging in the Lopé Reserve, central Gabon. Biological Conservation, 86(1), 15-20.

Brugière, D., Gautier, J.-P. \& Lahm, S. (1998) Additional data on the distribution of Cercopithecus (lhoesti) solatus. Folia Primatologica, 63(5), 331-336.

Butynski, T. (1996) International trade in CITES Appendix II African primates. African Primates, 2(1), 5-9.

Doucet, J.-L. (1996) Régénération naturelle en Forêt des Abeilles. Inventaires, écologie des espèces et impact de l'exploitation. Faculté des Sciences Agronomiques, Gembloux, Belgique et Station de Recherche de la Makandé, Gabon.

Dutrillaux, B., Dutrillaux, A.-M., Lombard, M., Gautier, J.-P., Cooper, R., Moysan, F. \& Lernould, J.-M. (1988) The karyotype of Cercopithecus solatus Harrison 1988, a new species belonging to $C$. lhoesti, and its phylogenic relationships with other guenons. Journal of Zoology, London, 215, 611617. 
Fleury, M.-C. \& Gautier, J.-P. (1998) Apprentissage du milieu naturel par un jeune Cercopithecus solatus sauvage élevé à la main. Revue d'Ecologie (Terre \& Vie), 53, 201-215.

Gautier, J.-P. (1988a) Interspecific affinities among guenons as deduced from vocalizations. In A Primate Radiation. Evolutionary Biology of the African Guenons (eds A. GautierHion, F. Bourlière, J.-P. Gautier and J. Kingdom), pp. 194-226. Cambridge University Press, Cambridge, UK.

Gautier, J.-P. (1988b) Le point sur le statut de Cercopithecus (lhoesti) solatus. Rapport pour la Direction de la Faune et de la Chasse, Libreville, Gabon. Laboratoire de Primatologie \& Biologie Evolutive, Université de Rennes I, France.

Gautier, J.-P. (1988c) New species of Cercopithecus in Gabon needs protection. Primate Conservation, 9, 27-28.

Gautier, J.-P. \& Elkin, L. (1995) Preliminary results on the ecology and behaviour of the sun-tailed guenon (Cercopithecus lhoesti solatus, Harrison): use of radio-tracking (abstract). Folia Primatologica, 64(1-2), 81.

Gautier, J.-P., Moysan, F., Feistner, A.T.C., Loireau, J.-N. \& Cooper, R.W. (1992) The distribution of Cercopithecus (lhoesti) solatus. An endemic guenon of Gabon. Revue d'Ecologie (Terre \& Vie), 47, 367-381.

Harrison, M.J.S. (1988a) A new species of guenon (genus Cercopithecus) from Gabon. Journal of Zoology, London, 215, 561-575.

Harrison, M.J.S. (1988b) New guenon from Gabon. Oryx, 22(4), 190-191.

IUCN (1996) 1996 Red List of Threatened Animals. IUCN-The World Conservation Union, Gland, Switzerland.

Kingdon, J. (1997) The Kingdon Field Guide to African Mammals. Academic Press, London, UK.

Lasserre, F. \& Gautier-Hion, A. (1995) Impacts environnementaux d'une exploitation sélective en forêt tropicale: l'Okoumé en Forêt des Abeilles. Le cas de la Société Leroy-Gabon. Laboratoire de Primatologie \& Biologie Evolutive, Université de Rennes I, France et Station de Recherche de la Makandé, Gabon.

Lee, P.C., Thornback, J. \& Bennett, E.L. (1988) Threatened Primates of Africa. IUCN Red Data Book. IUCN-The World Conservation Union, Gland, Switzerland.

Lernould, J.-M. (1988) Classification and geographical distribution of guenons: a review. In A Primate Radiation. Evolutionary Biology of the African Guenons (eds A. Gautier-Hion, F. Bourlière, J.-P. Gautier and J. Kingdom), pp. 54-77. Cambridge University Press, Cambridge, UK.

Malbrant, R. \& Maclatchy, A. (1949) Faune de l'Equateur Africain Français. Tome II: Mammiferes. Lechevalier, Paris, France.

McShane, T.O. (1990) Conservation before the crisis-an opportunity in Gabon. Oryx, 24, 9-14.

Oates, J.F. (1986) Action Plan for the Conservation of African Primates: 1986-1990. IUCN-The World Conservation Union, Gland, Switzerland.

Oates, J.F. (1996) African Primates. Status Survey and Conservation Action Plan, revised edn. IUCN-The World Conservation Union, Gland, Switzerland.
Pearce, J. (1996) Wildlife and Timber Exploitation in Gabon. A Case Study of a Leroy Concession, Forêt des Abeilles. World Society for the Protection of Animals, London, UK.

Peignot, P., Fontaine B. \& Wickings J. (1996) Cercopithecus solatus: what's known and what we are learning from a semi-free ranging colony at CIRMF in Gabon. In Abstract of the XVI Congress of the International Primate Society, Madison, USA, August 1996 (ed. International Primate Society), pp. 85, abstract 215. Washington DC, USA, IPS.

Steel, E. (1994) Etude sur le volume et la valeur du commerce de la viande de brousse au Gabon. WWF-Gabon, Libreville, Gabon.

Tutin, C.E.G. (1992) Gabon. In The Conservation Atlas of Tropical Forests-Africa (eds J. A Sayer, C. S. Harcourt and N. M. Collins), pp. 168-174. Macmillan, UK.

Usongo, L. \& Curran, B. (1996) Le commerce de la viande de chasse au sud-est du Cameroun dans la région trinationale. African Primates, 2(1), 2-5.

White, L.J.T. (1992) Vegetation history and logging disturbance: effects on rain forest mammals in the Lopé Réserve, Gabon (with special emphasis on elephants and apes). $\mathrm{PhD}$ thesis, University of Edinburgh, UK.

White, L.J.T. \& Mackanga, A. (1995) Good news for Cercopithecus solatus, Gabon's endemic guenon. African Primates, 1(1), $6-8$

Wilks, C. (1990) La Conservation des Écosystèmes Forestiers du Gabon. IUCN-The World Conservation Union, Gland, Suisse.

Wilson, D.E. \& Reeder, D.M. (1993) Mammal Species of the World. A Taxonomic and Geographic Reference. Smithsonian Institution Press, Washington DC, USA.

\section{Biosketches}

D. Brugière recently presented his $\mathrm{PhD}$ thesis on the determinants of variation in Central African forest primate biomass. He currently works at the Ethologie, Evolution and Ecologie laboratory (UMR 6552, formerly Primatologie and Biologie Evolutive) of the University of Rennes, France. He is conducting field surveys in Central Africa under the European Union's ECOFAC project and his main research interests are primate community structure and conservation

J.-P. Gautier, head researcher at the Ethologie, Evolution and Ecologie laboratory (UMR 6552, formerly Primatologie and Biologie Evolutive), University of Rennes, has worked since 1965 on the socio-ecology and behaviour of cercopithecine species in Central African rain forests. He has undertaken comparative studies on acoustic communication in various species in the field and in the laboratory Since 1984 his scientific activity has focused mainly on the geographical distribution and the socio-ecology of the suntailed guenon. 